\title{
ГАЗАР ХӨДЛӨЛТИЙН ХУЧИЙГ СЕЙСМ ДОЛГИОНЫ ҮРГЭЛЖИЛСЭН ХУГАЦААГААР ТОДОРХОЙЛОХ НЬ
}

\author{
Д. Мөнгөнсүрэн ${ }^{1}$, М. Өлзийбат ${ }^{l}$ \\ ШУА-ийн Одон орон, геофизикийн судалгааны төв \\ Цахим шуудан: mungun_m@yahoo.com,ulziibat@iag.ac.mn
}

\section{ОРШИЛ}

Шинжлэх ухаан, технолог улам хурдацтай хөгжихийн хэрээр газар хөдлөлийн судалгааны багаж техник технологи улам боловсронгуй болж газрын гүнд болж буй өчүүхэн эвдрэлээс үүссэн сейсм долгионыг бүртгэж авах боломж нээгдсэнээр сул газар хөдлөлтүүдээс үүссэн доргилтыг нанометрийн $\left(10^{-9}\right.$ мм $)$ түвшинд бүртгэн авч тодорхойлж байна. Гэвч энэхүҮ өндөр мэдрэмжийн сейсмостанцуудын сейсм долгион бүртгэх боломжийн хязгаараас хамаарч хүчтэй, зарим тохиолдолд дунд зэргийн хүчтэй газар хөдлөлтийн сейсм долгионы далайцыг бүртгэж тухайн газар хөдлөлтийн хүчийг тодорхойлоход хүндрэл учирдаг. Тухайн сейсмостанцаас 100 км-ээс дотогш зайд болсон газар хөдлөлтүүдийн хувьд сейсм долгионы замхралт ба орчны геологийн нөхцөл хоорондын зайнаас хамаарсан шулуун хамаарал алдагддаг тул газар хөдлөлтийн хүчийг шууд тодорхойлох боломжгүй. Иймээс газар хөдлөлтийн хүчийг сейсм долгионы үргэлжилсэн хугацаагаар тодорхойлох аргыг хэрэглэдэг болно.

Газар хөдлөлийн сейсм долгионыг багажинд бүртгэж эхэлсэн хугацаанаас уг газар хөдлөлтийн бичлэгийн далайцын түвшин замхарсаар газар хөдлөхийн өмнөх түвшинд хүртлэх хугацааг тухайн газар хөдлөлтийн долгионы үргэлжилсэн хугацаа гэнэ (1-p зураг).

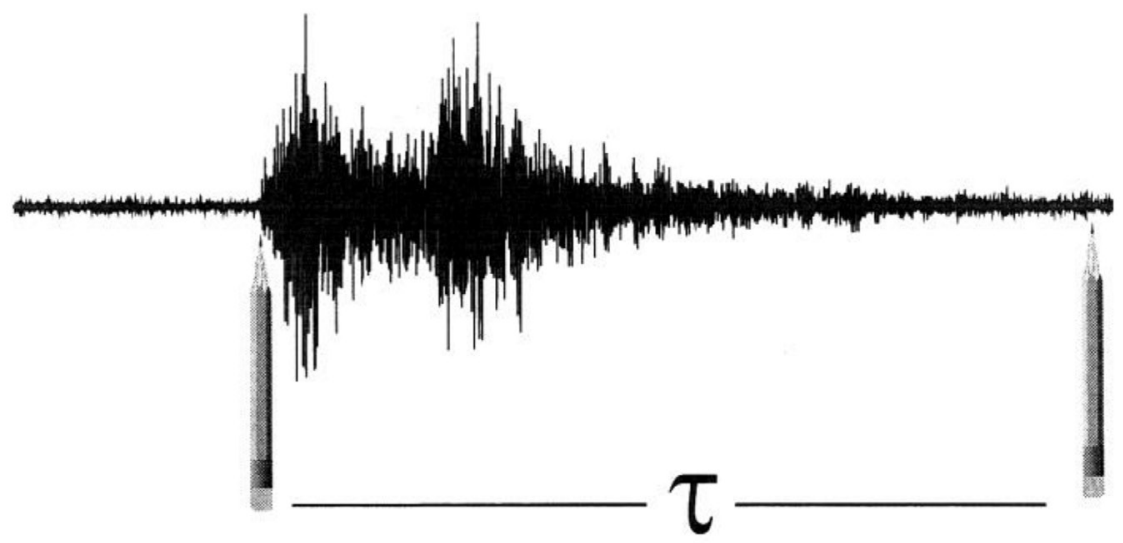

1-р зураг. Сейсм долгионы үргэлэллэх хугаиаа

Tүлхүур үг: Рихтерийн магнитуд, сейсм долгионы үргэлжилсэн хугацаа, долгионы замхралт, 


\section{Ажлын үндэслэл болон зорилго}

1994 оноос Монгол орны газар хөдлөлтийг бүртгэх станцын сүлжээнд техник технологийн шинэчлэл хийж, мэдээллийг алсаас дамжуулдаг, орчин үеийн тоон бичлэгтэй, электрон багаж төхөөрөмжөөр тоноглосон, өндөр (хөрсний шилжилтийг нанометрийн (10-9 мм) түвшинд бүртгэх) хүчин чадалтай бичил сүлжээ станц ажиллаж эхэлсэн, мөн эдгээр станцын бичлэгээс хүчтэй болон 100 км-ын радиуст болсон сул газар хөдлөлтийн хүчийг үргэлжилсэн хугацаагаар тодорхойлох нөхцөл бүрдсэн зэрэг нь судалгааг хийх үндэслэл болсон.

Бидний энэхүу судалгааны ажлын зорилго нь Монгол орны нутаг дэвсгэрт болж буй газар хөдлөлтийн голомтоос тархаж буй сейсм долгионы замхралтын хуулийг үндэслэн ойрын зайн газар хөдлөлтийн хүчийг долгионы үргэлжилсэн хугацаагаар тодорхойлох томъёог гаргахад оршино. Энэ томъёог гаргаснаар газар хөдлөлтийн мэдээллийн санд хадгалагдаж байгаа ойрын зайны олон мянган сул газар хөдлөлтийн хүчийг тодорхойлох, улмаар тухайн бүс нутгийн газар хөдлөлтийн горим болон идэвхжилтийг судлах боломжийг нээж өгч байгаа явдал юм.

\section{Судалгааны арга зүй}

Долгионы үргэлжилсэн хугацаагаар газар хөдлөлтийн магнитудыг тодорхойлох үндсэн аргачлал нь Рихтерийн магнитуд, долгионы үргэлжилсэн хугацаа, газар хөдлөлтийн төвийн зай болон тухайн багажийн мэдрэх чадвар ба эдгээрийн хоорондын хамаарлыг тогтооход орших ба үҮнийг томьёолон үзүүлбэл:

$$
M d=a+b^{*} \log (\tau)-c^{*} \Delta
$$

Үүнд: $M d$ - үргэлжилсэн хугацааны мангитуд; $\tau$ - долгионы үргэлжилсэн хугацаа; $\Delta$ - газар хөдлөлтийн төвийн зай; $a, b, c$-коэффицентүүд

\section{Судалгаанд ашигласан мэдээллийн сан ба боловсруулалт}

Аливаа судалгаанд ашиглах анхан шатны мэдээллийн сангийн бүрдүүлэлт нь судалгааны үр дүнг чанарын өндөр түвшинд гаргахад чухал ач холбогдолтой. Энэхүу судалгааны ажилд 2004 - 2006 оны хоорондох хугацаанд Монгол орны тоон бичлэгтэй 21 сүлжээ станцуудад бүртгэгдсэн газар хөдлөлтийн мэдээллийг анхан шатны материал болгон авсан. Дээрх хугацаанд бүртгэгдсэн нийт газар хөдлөлт тус бүрийн сейсм долгионы бичлэгт дүн шинжилгээ хийсний дүнд тодорхой хэд хэдэн шалгуураар 200 газар хөдлөлтийн мэдээллийг сонгон авсан болно.

\section{Эдгээр шалгуурт:}

- $\quad$ Газар хөдлөлтийн бичлэг нь дундаa тасралтгүй үргэлжилсэн бөгөөд бидний сонгосон станц бүрт бүртгэгдсэн байх

- Газар хөдлөлтийн бичлэгийн сигнал болон шумын харьцаа нь зохистой түвшинд байх

- Тухайн сонгосон газар хөдлөлтүүд нь азимут болон зайны хувьд боломжит бүхий л бүс нутгийг хамарсан байх

Мөн газар хөдлөлтүүдийг магнитудыг $(2$ - 6)-тай байхаар сонгосон. $\mathrm{M}<$ 2 бага газар хөдлөлтүүдийн Рихтерийн магнитуд нь ихэвчлэн тодорхойлох боломжгүй өөрөөр хэлбэл тухайн станцаас 100 км дотор болсон газар хөдлөлт байдаг тул $\mathrm{Md}$ хамаарлыг тогтоох боломжгүй. Мөн магнитуд нь 6 ба түүнээс дээш хүчтэй газар хөдлөлтүүдийн дараа давталт газар хөдлөлтүүд түр хугацаанд үргэлжилдэг тул долгионы үргэлжилсэн хугацааг тогтооход бэрхшээлтэй байдаг.

Эдгээр шалгууруудыг үндэслэн сонгосон газар хөдлөлт ба түүнийг бүртгэсэн станц бүрийн хувьд долгионы үргэлжилсэн хугацааны хэмжилтийг ONYX програмын тусламжтайгаар хийж гүйцэтгэсэн.

Долгионы үргэлжилсэн хугацааг 
дараахь хоёр янзаар хэмжиж сейсм долгионы үргэлжилсэн хугацаагаар магнитуд $(M d)$-г тодорхойлох боломжтой.

Нэгдүгээрт: Газар хөдлөлтийн долгион бичигдэж эхэлсэн хугацаанаас эхлээд тухайн долгионы хамгийн их амплитудын $1 / 3$ хүртлэх хэмжээнд хүртэл буурсан долгионы үргэлжилсэн хугацаагаар тодорхойлох.

Хоёрдугаарт: Газар хөдлөлтийн анхны долгион ирж бүртгэгдсэн үеэс эхлэн бүтэн замхралт явагдаж дуусах хугацаа буюу шулуун долгион Р бүртгэгдсэн хугацаанаас эхлэн долгион нь бүрэн замхарч эхний шумын түвшиндээ орох хүртлэх үргэлжилсэн хугацаагаар тодорхойлох.

Энэхүу судалгаандаa бүтэн үргэлжилсэн хугацааны хувьд $\mathrm{Md}$ тодорхойлсон болно.

\section{Судалгааны үр дүн}

Монгол орны нөхцөлд тохирсон долгионы үргэлжилсэн хугацаагаар тухайн газар хөдлөлтийн магнитудыг тодорхойлох зорилгоор хийсэн судалгааны ажилд нэг газар хөдлөлтийн хувьд бүртгэсэн станц бүрийн хувьд Md-г тодорхойлсон ба доорхи томъёогоор станц бүрийн хувьд $a, b, c-$ коэффиецентүүдийн бодож дундаж утгыг гаргасан[5].

$$
M_{(i, j)}=a+b * \log \left(\tau_{(i, j)}\right)-c^{*} \Delta_{(i, j)}
$$

Энэхүү аргаар бүс нутгийн геологийн онцлогийг тусгасан хэд хэдэн томъёог гаргах боломжтой ба сонгож авсан мэдээллийнхээ чанар, нарийвчлалыг шалгах зорилгоор газар хөдлөлтийн үргэлжилсэн хугацааны логорифм утга болон тодорхойлогдсон Рихтерийн магнитуд хоорондын хамаарлыг шулуун регрессын аргаар тооцож үзсэн. Энэхүу шалгалтын үр дүнгээс үзэхэд бидний сонгосон станцуудад хэмжсэн үргэлжилсэн хугацаа болон магнитудын хоорондын корреляцын коэффициент (R) нь $0.8-0.9$ хооронд буюу алдааны хязгаарт багтаж байгаа нь судалгаа явуулахад хангалттай мэдээлэл болсон гэж үзэв.

$$
\text { Нийтдээ } 18 \text { станцын хувьд }
$$
үргэлжилсэн хугацаа, төвийн зай болон Рихтерийн магнитуд хоорондын хамаарлыг олон утгат регрессийн ба хамгийн бага квадратын аргаар тооцож олсон. Үүнийг тооцохдоо “ Matlab” математик боловсруулалтын программыг ашиглан олон утгат регрессын аргаaр коэффицентүүдийг олсон болно.

ЭнэХүҮ регрессийн аргаар тооцоож гаргасан $a, b, c-$ коэффиецентүүдийн дундаж утгыг станц тус бүрээр (1-p хүснэгт)-д харуулав.

1-р хуснэгт

\begin{tabular}{|c|c|c|c|c|c|c|}
\hline Станцын нэр & $a$ & $b$ & $c$ & алдаa & $R$ & Хөдлөлийн тоо \\
\hline АLFM & -1.9228 & 2.0803 & 0.0008 & 0.37 & 0.8824 & 60 \\
\hline ARTM & -2.7712 & 2.3733 & 0.0007 & 0.34 & 0.8547 & 47 \\
\hline SEMM & -2.1542 & 2.1291 & 0.0008 & 0.41 & 0.8852 & 48 \\
\hline UGDM & -2.6142 & 2.4314 & 0.0001 & 0.25 & 0.919 & 11 \\
\hline SAOM & -2.1436 & 2.3313 & 0.0002 & 0.29 & 0.939 & 48 \\
\hline SA1M & -2.1789 & 2.4343 & 0.0001 & 0.32 & 0.8946 & 68 \\
\hline SA2M & -2.4217 & 2.5318 & 0.0001 & 0.30 & 0.9188 & 50 \\
\hline SA3M & -1.9786 & 2.2537 & 0.0003 & 0.30 & 0.8717 & 61 \\
\hline SA4M & -2.1013 & 2.2683 & 0.0002 & 0.40 & 0.8723 & 53 \\
\hline SB2M & -2.1503 & 2.3281 & 0.0003 & 0.37 & 0.8935 & 49 \\
\hline SB5M & 1.9557 & 2.1833 & 0.0006 & 0.31 & 0.8834 & 58 \\
\hline HO1M & -1.9957 & 1.9799 & 0.0007 & 0.36 & 0.8249 & 51 \\
\hline \hline HO2M & -2.3364 & 2.0801 & 0.0011 & 0.38 & 0.8424 & 51 \\
\hline HO3M & -2.1363 & 2.0028 & 0.0009 & 0.36 & 0.8294 & 53 \\
\hline
\end{tabular}




\begin{tabular}{|l|l||c|c|c|c|c|}
\hline HO4M & -1.8514 & 1.7677 & 0.0016 & 0.39 & 0.8012 & 56 \\
\hline \hline HO5M & -2.2397 & 2.0546 & 0.0007 & 0.35 & 0.8619 & 56 \\
\hline HO6M & -2.0383 & 1.9018 & 0.0011 & 0.33 & 0.8636 & 57 \\
\hline \hline HO7M & -2.3123 & 1.9619 & 0.0017 & 0.36 & 0.8438 & 56 \\
\hline
\end{tabular}

Тухайн бүс нутгийн царцдасын зузаан болон сейсм долгионы замхралтын нөхцөлөөс хамаарч долгионы үргэлжилсэн хугацаа ба зайны хамааралууд нь нэг улсын нутаг дэвсгэрийн хувьд ч өөр өөр утгатай байдаг $[1,14]$.

Дээрхи хүснэгтэнд үзүүлсэн үр дүнгээс үзэхэд долгионы үргэлжилсэн хугацаа ба зайны хамааралын коеффициент

Баруун монголын бүсэнд байрлалтай станцын хувьд:

$$
\operatorname{Md}(H o)=-2.1764+1.9969 * \log (\tau)+0.001 * \Delta
$$

Төв болон зүүн хэсэгт байрлалтай станцын хувьд:

$$
M d(U B)=-2.1478+2.2797 * \log (\tau)+0.0004 * \Delta
$$

үргэлжилсэн хугацаагаар газар хөдлөлтийн магнитудыг тодорхойлох томъёог дээрхи хэлбэрээр гаргав.

Дээрхи томъёогоор бодогдсон $\mathrm{Md}$ ба Рихтерийн мангитуд хоёрыг харьцуулж энэ хийсэн судалгаагаар гаргасан томъёоны алдааны хязгаарыг тооцож үзэхэд Улаанбаатар болон Ховдын станцуудын хувьд алдааны хүрээ +/-0.28 гарсан. Төрөл бүрийн магнитуд хоорондын зөвшөөрөгдөх алдааны хязгаарт энэхүү утга нь багтсанаар эдгээр томъёог цаашдын боловсруулалтанд ашиглах боломжтойг харуулж байна.

Мөн ойрын газар хөдлөлтийн Ml ба судалгаа хийж тодорхойлсон $\mathrm{Md}-\mathrm{bH}$ хоорондын хамаарлыг тогтоосон болно.

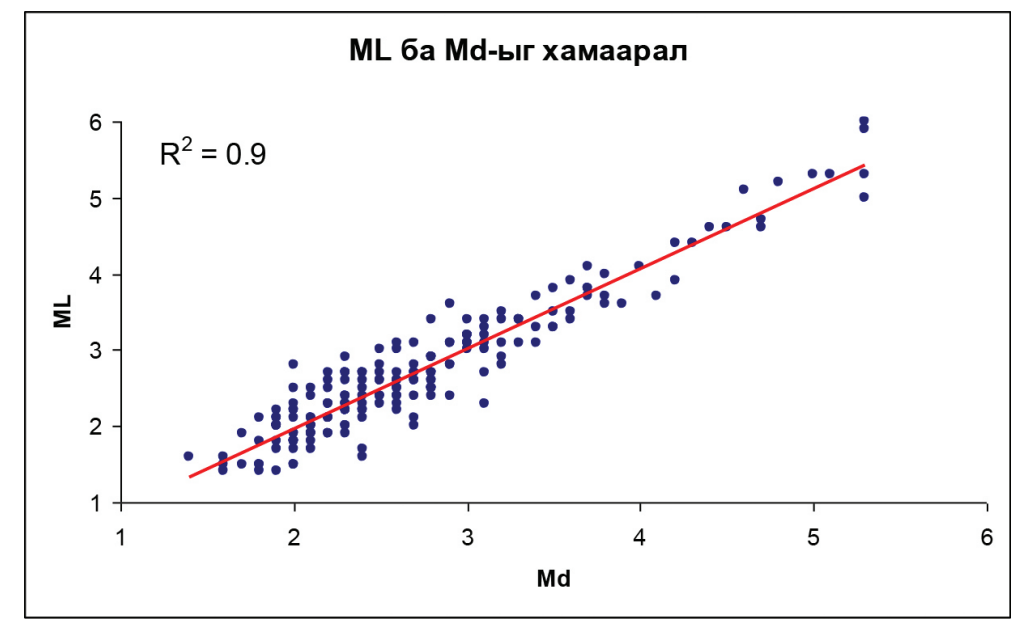

$\mathrm{Ml}=1.05 * \mathrm{Md}-0.15$ 


\section{ДҮГНЭЛТ}

1. Монголыг нутаг дэвсгэрийн геолог, тектоникийн нөхцөлд уялдуулсан $\mathrm{Md}$ магнитуд (долгионы үргэлжилсэн хугацааны магнитуд) -ыг тодорхойлох томъёоллыг бодож гаргав.

2. Тухайн газар хөдлөлтийн сейсм долгионы үргэлжилсэн хугацааг хэмжих аргачлалыг боловсруулсан бөгөөд үүний үр дүнд мэдээллийг нэгдсэн нэг системээр хэмжилт хийх нөхцөлийг бүрдүүлсэн болно.

3. Одоогоор Газар хөдлөлийн секторын мэдээллийн санд хадгалагдаж буй магнитуд нь тодорхойлогдоогүй 10000 гаруй газар хөдлөлтийн магнитудыг нөхөн тодорхойлох боломжийг нээсэн болно.

4. $\mathrm{Md}$ болон Ml магнитуд хоорондын хамаарлыг тогтоож өгснөөр газар хөдлөлтийн цаашдын судалгаанд ялангуяа орон нутгийн чанартай сул газар хөдлөлтийн идэвхижилтийг нарийвчлах, бүс нутгийн газар хөдлөлтийн горимын судалгааг нарийвчлалтай хийх нөхцөлийг бүрдүүлсэн болно.

\section{Ашигласан бүтээлийн жагсаалт}

1. И.Балжинням, А.Мөнхөө Д, Б.Цэмбэл, Т.Дугармаа, М.Адъяа, Г.Баяр “Монгольин газар хөдлөхүй”, Улаанбаатар, 1975

2. Д.Мөнхөө, Т.Дугармаа “Монгольн газар хөдлөлийн горим”. Физик математикийн хүрээлэн. № $10-11.1972$.

3. И. Балжинням "Монгольн газар хөдлөлийг багажаар судлах асуудал". Физик математикийн хүрээлэн. № $10-11.1972$.

4. М.Адъяа, И.Балюсинням, Д.Мөнхөө, Т.Дугармаа "1972 онд Монголд болсон газар хөдлөл". Физик математикийн хүрээлэн. № 12. 1974.

5. Lee, W. H., Bennett, R. E., and Meagher, K. L., 1972. "A Method of Estimating Magnitude of local earthquakes from signal duration”. U.S. Geological Survey Open-File Report, 28p.

6. Gutenberg B.B (1956), “Great earthquakes 1896-1903”., Trans. Amer.Geophys. Union, vol.37, N5, p. 608-614

7. Gutenberg.B., et C.F.Richter (1944), "Frequency Earthquakes in California", Bull. Seism. Soc. Am. 34, p.1985-1988

8. Gutenberg,B., et C.F.Richter (1956), "Earthquake magnitude, intensity, energy and acceleration”. Bull. Seism. Soc. Am., 1956, v46,№1,105-145

9. Richter, C., 1958. "Elementary seismology". Freeman and Co., San Francisco, pp 768.

10. Bormann. P., Chapter 3: Seismic Sourse and Sourse Parameters IASPEI, NMSOP, , Volume 1, 2002

11. С.Д.Хилъко, Р.А.Куришин, В.М.Кочетков, Л.А.Мишарина, В.И.Мельникова, Н.А.Гильева, С.В.Ласточкин, И.Балжсиням,Д.Мөнхөө Землетрясения и основы сейсмического районирования Монголии " Москва, Наука, 1985 г

12. Н.В.Кондорская, И.Л.Нерсосов, И.В.Горбунова, Т.Г.Раутиан "Магнитудаи энергетическая классификачия землетрясений” Том I и Том II, Москва, 19742.

13. Paolo. Gasperini "Local magnitude revalution for recent Italian earthquakes (1981 - 1996)" Journal of Seismology 6: 503-524, 2002

14. Nassir S. Al-Arifi "Local and Regional Md calibration of Tabuk Subnetwork, NW of Saudi Araba”, Saud Univ. Vol. 12, Science, pp. 41-55.

15. Bisztricsany, E., 1958. "A new method for the determination of the magnitude of earthquakes", Geofiz. Kozl., Volume 7, pp. 69-96 (in Hungarian with English abstract).

16. Richter, C. F., 1935. "An Instrumental Earthquake Magnitude Scale”. Bulletin Seismological 
Society Amer, Volume 25, p. 1-32.

17. Tsumura, K., 1967. "Determination of earthquake magnitude from total duration of oscillation”, Bulletin Earthquake Res. Inst., Tokyo Univ., Volume 45, pp. 7-18.

18. Thorne Lay and Terry C. Wallace "Modern Global Seismology", International Geophysics Series, Volume 58, 1995

19. Bayasgalan, A. (1999), "Active Tectonics of Mongolia", PhD thesis, University of Cambridge, Cambridge, $182 \mathrm{pp}$

20. Флоренсов Н.А., Солоненко.П., “Гоби-Алтайское землетрясение” Изд-во АН СССР, 1963

21. Тресков А.А, “Вопросы сейсмичности Сибири”, 1964

22. W.H.K.Lee, M.S. Eaton, E.E.Brabb, "The earthquake sequence near Danville, California, 1970”. Bulletin of the Seismological Society of America; December 1971; v.61; no.6; p.17711794. 


\title{
ESTIMATING MAGNITUDE OF LOCAL EARTHQUAKES FROM SIGNAL DURATION
}

\author{
Dashdondog MUNGUNSUREN $N^{1}$ : and Munkhuu ULZIIBAT \\ ${ }^{1}$ Research center of Astronomy and Geophysics, Mongolian Academy of Sciences (RCAG, MAS), \\ Ulaanbaatar, Mongolia \\ E-mail:mongon@rcag.ac.mn,ulzibat@rcag.ac.mn
}

\begin{abstract}
To perform duration magnitude in Mongolia, we used the seismic signals recorded at the seismic networks of Ulaanbaatar and Hovd (Altay range). Using data from earthquakes in the 2 to 6 magnitude range, we performed a multiple regression analysis and we got two new duration magnitude relationships: $\mathrm{Md}=-2.1764+1.9969 \log (\tau)+0.001 \Delta$, using Hovd records, and $\mathrm{Md}=-2.1478+2.2797 \log (\tau)+0.0004 \Delta$, using Ulaanbaatar rdcords. ( $\tau=$ seismic signal duration and $\Delta=$ station corrections). Station corrections range \pm 0.28 . The source-receiver distance and the local geology conditions affect the signal duration. The new magnitudes are calibrated with a local magnitude scale previously defined for the region.
\end{abstract}

KEY WORDS: Duration magnitude, Signal duration, Local magnitude, Station correction., 